\title{
Problematika dan Strategi Pembelajaran pada Masa Pandemi di Wilayah Pesisir Kepulauan Buton
}

\author{
Firman Alamsyah Mansyur ${ }^{1}$, Fahmil Ikhsan Taharu ${ }^{\text {* }}$ \\ 1 Universitas Muhammadiyah Buton, Indonesia \\ *Korespondensi: amilbiosz08@gmail.com
}

\begin{tabular}{|c|c|}
\hline & \\
\hline $\begin{array}{r}\text { Dite } \\
\text { Septer } \\
\text { Dis } \\
\text { Nover }\end{array}$ & $\begin{array}{l}\text { Penelitian ini bertujuan menjelaskan problematika dan strategi sekolah dan } \\
\text { guru di wilayah pesisir kepulauan Buton dalam melaksanakan } \\
\text { pembelajaran pada masa pandemi Covid-19. Metode penelitian ini adalah } \\
\text { deskriptif kualitatif. Pengumpulan data primer dilakukan dengan } \\
\text { penyebaran angket secara online, observasi, dan wawancara. Informan } \\
\text { penelitian berasal dari unsur guru, kepala sekolah SMA, peserta didik dan } \\
\text { orang tua peserta, khususnya SMA Muhammadiyah. Data sekunder } \\
\text { diperoleh melalui kajian literature. Analisis data kualitatif penelitian ini } \\
\text { dilakukan melalui beberapa tahapan, yaitu reduksi data, penyajian data, }\end{array}$ \\
\hline $\begin{array}{r}\text { Key } \\
\text { Co } \\
\text { Kepulal } \\
\text { Prob } \\
\text { Pem }\end{array}$ & $\begin{array}{l}\text { interpretasi data, dan penarikan kesimpulan terkait kajian ini. Hasil kajian } \\
\text { ini mengungkapkan bahwa terdapat berbagai persoalan dalam } \\
\text { pelaksanaan pembelajaran di Sekolah Menengah Atas pada masa } \\
\text { pandemic-Covid-19. Persoalan yang terjadi sangat terkait dengan } \\
\text { ketidaksiapan sekolah, guru, orang tua, dan peserta didik dalam } \\
\text { menghadapi transformasi pembelajaran pada masa pandemic. Selain itu, }\end{array}$ \\
\hline $\begin{array}{l}\text { (c) } 2021 \text { The } \\
\text { Author(s): This is } \\
\text { an open-access } \\
\text { article distributed } \\
\text { under the terms of } \\
\text { the Creative } \\
\text { Commons } \\
\text { Attribution } \\
\text { ShareAlike (CC BY- } \\
\text { SA 4.0) }\end{array}$ & $\begin{array}{l}\text { ketidaksiapan jaringan juga sangat mempengaruhi transformasi } \\
\text { pembelajaran dari luring ke daring menjadi tidak efektif. Oleh karena itu, } \\
\text { tedapat berbagai strategi yang coba diterapkan oleh sekolah dan guru } \\
\text { untuk melaksanakan pembelajaran, baik secara online maupun tatap } \\
\text { muka melalui pertemuan kelas dan kunjungan rumah secara terbatas. } \\
\text { Hasil kajian ini menunjukkan bahwa pelaksanaan pembelajaran pada } \\
\text { masa pandemic tidak berjalan secara efektif akibat persoalan yang sangat } \\
\text { kompleks. Peranan pemerintah sangat penting dalam menyiapkan sarana } \\
\text { dan prasarana pendukung pelaksanaan pembelajaran pada masa } \\
\text { pandemic Covid-19. } \\
\text { Abstract }\end{array}$ \\
\hline & $\begin{array}{l}\text { This study aims to explain the problems and strategies of schools and } \\
\text { teachers in coastal areas of the Buton islands in carrying out learning } \\
\text { during the Covid-19 pandemic. This research method is descriptive } \\
\text { qualitative. Primary data are collected through online questionnaires, } \\
\text { observations, and interviews. Research informants come from the } \\
\text { elements of teachers, high school principals, students and parents of } \\
\text { participants, especially Muhammadiyah High School. Secondary data is } \\
\text { obtained through literature studies. The data are analyzed using qualitative } \\
\text { data analysis method consisting of data reduction, data presentation, data } \\
\text { interpretation and conclusion drawing. From the results of the study, it is } \\
\text { concluded that there are various problems in the implementation of } \\
\text { learning in high schools during the pandemic-Covid-19. The problems are } \\
\text { strongly related to the unpreparedness of schools, teachers, parents, and }\end{array}$ \\
\hline
\end{tabular}


students in facing the transformation of learning during the pandemic. In addition, network unpreparedness also greatly affects the transformation of learning from offline to online to ineffective. Therefore, there are various strategies that schools and teachers try to implement to carry out learning, both online and face-to-face through limited class meetings and home visits. The results of this study show that the implementation of learning during the pandemic does not run effectively due to very complex problems. The role of the government is very important in preparing facilities and infrastructure to support the implementation of learning during the pandemic covid-19.

\section{Pendahuluan}

Pandemi Covid-19 merupakan persoalan global yang telah mempengaruhi pelbagai aspek kehidupan manusia (Pertiwi \& Syakarofath, 2020). Covid-19 pertama kali dilaporkan kepada WHO pada tanggal 31 Desember 2019 (World Health Organization, 2021). Wabah Covid-19 ini kemudian menyebar di pelbagai negara. Oleh karena itu, WHO menegaskan bahwa Covid-19 merupakan suatu persoalan kesehatan dengan status darurat global. Indonesia merupakan salah satu negara yang wilayahnya sangat strategis bagi penyebaran Covid-19 karena sangat tingginya aktivitas warga negaranya, dan warga negara asing yang datang ke Indonesia untuk melakukan pelbagai kegiatan, baik kegiatan ekonomi, pendidikan, politik, budaya, pariwisata, maupun kegiatan lainnya.

Pada saat ini, Indonesia adalah salah satu negara yang telah terkonfirmasi Covid-19. Covid-19 sehingga berdampak pada sektor kesehatan, pariwisata, ekonomi, sosial, dan pendidikan. Mansyur (2020a) mengemukakan beberapa dampak Covid-19 bagi dinamika pembelajaran di Indonesia, yaitu: a) transformasi tempat pembelajaran yang bertempat di sekolah berubah menjadi di rumah siswa atau tempat lainnya di luar sekolah; b) transformasi media pembelajaran berbasis teknologi dengan pelbagai platform media pembelajaran, yaitu: WhatsApps, Zoom,Google classroom, WebEx, Youtube, dan TV; c) penyesuaian metode pembelajaran; d) penyesuaian evaluasi pembelajaran untuk penetapan standar kelulusan atau naik kelas siswa; e) tuntutan kolaborasi orang tua untuk mendampingi siswa di rumah.

Kementerian Pendidikan dan Kebudayaan menetapkan bahwa proses pembelajaran di masa pandemi harus mengalami transformasi dengan penyesuaian sesuai kondisi yang terjadi, semula dilaksanakan melalui tatap muka di ruangan kelas pada sekolah masing-masing berubah menjadi dalam jaringan dengan bantuan alat teknologi atau dengan berbagai bantuan lainnya tanpa melalui pembelajaran tatap muka di kelas atau dikenal dengan pembelajaran jarak jauh (Sekretariat GTK, 2021). Skenario pembelajaran yang diselenggarakan oleh guru haruslah disesuaikan dengan jenis tujuan pembelajaran yang hendak dicapai oleh peserta didik. keberhasilan proses pembelajaran ditentukan bagaimana guru melakukan manajemen kelas dan pengaturan-pengaturan pada proses pembelajaran (Sunhaji, 2014).

Purwanto et al. (2020) menyatakan bahwa banyak tantangan yang dihadapi selama pembelajaran di masa pandemi Covid 19 dan tantangan ini tidak hanya dialami oleh peserta didik dan orang tua tetapi juga oleh guru. Pembelajaran jarak jauh menyediakan tantangan tersendiri bagi guru dalam memberikan pengalaman belajar kepada peserta didik di masa pandemi. Tantangan tersebut adalah 
bagaimana memfasilitasi dan mengembangkan kompetensi peserta didik, baik kognitif, afektif, maupun psikomotoriknya, meskipun tanpa melalui pembelajaran tatap muka. Hal tersebut menuntut para guru untuk beradaptasi dalam melakukan pengaturan kelas selama proses pembelajaran mengingat peserta didik yang sebelumnya berkumpul dan belajar dalam satu ruangan bersama, saat ini men jadi belajar secara terpisah dengan menggunakan teknologi.

Proses pembelajaran yang baik mestilah ditunjang oleh sarana dan prasarana yang memadai (Novita, 2017). Penyesuaian kegiatan pembelajaran di masa pandemi membutuhkan kesiapan sarana dan prasarana yang mendukung. Proses penyesuaian kegiatan pembelajaran dan proses pendidikan di sekolah ini terjadi di seluruh wilayah Republik Indonesia yang merupakan wilayah maritim dengan pelbagai karakteristik wilayah yang dimilikinya, kesiapan sarana dan prasarana, akses dan sumberdaya yang berbeda-beda antara satu daerah dengan lainnya. Perbedaan kondisi tersebut menjadikan banyak wilayah khususnya di daerah pesisir perlu untuk mengidentifikasi kesiapannya.

Kesiapan sekolah-sekolah yang berada di kawasan pesisir berbeda antara satu dengan yang lainnya. Suatu sekolah ada yang berada di wilayah yang sudah memiliki akses internet termasuk memiliki sarana dan prasarana lain yang mendukung penyelenggaraan pembelajaran, akan tetapi masih ada juga sekolah yang terletak pada wilayah yang belum memiliki fasilitas internet dan sarana prasarana lainnya atau bahkan belum memiliki fasilitas listrik (Hartomo, 2020).

Perbedaan kondisi dan kesiapan sekolah-sekolah di wilayah pesisir yang terdiri atas pulau-pulau besar, kecil, dan terpencil, khususnya di Kepulauan Buton Provinsi Sulawesi Tenggara, menjadi penting diperhatikan dalam upaya penyelenggaraan pembelajaran secara optimal kepada peserta didik meskipun dalam situasi pandemi Covid-19. Oleh karena itu, pengkajian dan analisis yang mendalam mengenai kondisi dan kesiapan sekolah di wilayah maritim kepulauan Buton dalam menyelenggarakan pembelajaran perlu dilakukan.

Kajian terhadap pelaksanaan pembelajaran pada masa Pandemi Covid-19 telah dilakukan oleh banyak ahli. Jamal (2020) dalam kajiannya terkait Pembelajaran E-learning pada masa pandemic Covid-19 di SMK menyimpulkan enam aspek yang perlu disiapkan pada pelaksanaan pembelajaran di masa Covid 19, yatu; kesiapan peserta didik, kesiapan guru, kesiapan infrastruktur, dukungan managemen, budaya sekolah, dan kecenderungan terhadap tatap muka.

Abidin dkk. (2020) dalam kajiannya terkait pembelajaran online berbasis projek di tengah pandemi Covid-19 menjelaskan bahwa sistem pembelajaran online berbasis projek memberikan banyak peluang untuk mengakses bahan ajar oleh warga pembelajar. Terdapat beberapa platform media pembelajaran daring yang efektif dalam pengelolaan pembelajaran secara klasikal di antaranya adalah Google Classroom dan Edmodo. Namun demikian, terdapat beberapa kendala dalam pembelajaran online, di antaranya persoalan kuota internet yang terbatas dan masih belum familiarnya tenaga pendidik dan peserta didik dalam mengaplikasikannya.

Hutami \& Nugraheni (2020) dalam kajiannya terkait penggunaan aplikasi WhatsApps pada proses pembelajaran di PAUD selama masa Pandemi Covid-19 menyimpulkan bahwa harus ada komunikasi yang baik antara guru dengan orang 
tua siswa agar dapat memanfaatkan teknologis informasi dalam pembelajaran melalui daring, khususnya penggunaan whatsApps group.

Nurhayati (2020) dalam kajiannya terkait penggunaan media game edukasi quiz untuk meningkatkan keaktifan belajar siswa dalam pembelajaran daring menyimpulkan bahwa media game edukasi quiz dapat meningkatkan keaktifan siswa dalam pembelajaran daring pada masa pencegahan penyebaran Covid-19.

Sari (2020) mengkaji efektivitas penggunaan youtube dalam pembelajaran. Dari kajiannya, dia menyimpulkan bahwa yutube sangat efektif digunakan dalam pembelajaran namun tergantung pada kemampuan guru bagaimana menyajikan materi berbasis teknologi yang menarik dihadapan siswa.

Harahap dkk. (2020) mengkaji persoalan tingkatan stres akademik mahasiswa pada pembelajaran di masa Covid-19. Hasil kajian ini menyimpulkan bahwa rata-rata mahasiswa mengalami stres dalam kategori sedang. Selain itu, Oktawirawan (2020) menjelaskan persoalan yang menjadi pemicu kecemasan siswa selama pembelajaran dalam jaringan adalah sebagai berikut: kesulitan memahami materi, kesulitan mengerjakan tugas-tugas, ketersediaan dan kondisi jaringan internet, kendala teknis, dan kekhawatiran akan tugas selanjutnya.

Astini (2020) mengkaji tantangan dan peluang pemanfaatan teknologi informasi terhadap pembelajaran online di STKIP Agama Hindu Amlapura pada masa pandemi Covid-19. Pemberlakuan perkuliahan online menjadi pemicu percepatan proses transformasi digital pendidikan Indonesia karena sebelumnya berbagai wacana, kebijakan pendukung, serta sosialisasi tentang era pendidikan 4.0 belum berhasil. Namun Covid-19 justru memberikan dampak luar biasa terhadap transformasi digital menuju era pendidikan 4.0.

Wang et al. (2008) mengkaji model hubungan antara karakteristik psikologis dan hasil belajar peserta didik jarak jauh. Hasil dari penelitian ini menunjukkan bahwa ada hubungan antara karakteristik psikologis dan skor pembelajaran peserta didik. Pertama, ada hubungan antara efikasi diri, strategi belajar dan hasil belajar; kedua, ada hubungan antara efikasi diri, atribusi internal, motivasi belajar dan hasil belajar.

Mulyaningsih (2014) dalam kajiannya terkait pengaruh interaksi sosial keluarga, motivasi belajar, dan kemandirian belajar terhadap prestasi belajar siswa menyimpulkan beberapa hal berikut ini:

1) ada pengaruh yang signifikan antara interaksi sosial dalam keluarga, motivasi belajar, dan kemandirian belajar secara bersama-sama terhadap prestasi belajar siswa; 2) ada pengaruh yang signifikan interaksi sosial dalam keluarga terhadap prestasi belajar siswa; 3) ada pengaruh yang signifikan motivasi belajar terhadap prestasi belajar siswa, dan 4) ada pengaruh yang signifikan antara kemandirian belajar terhadap prestasi belajar siswa.

Syukur (2014) mengkaji bagaimana persepsi guru Sekolah Dasar, Sekolah Menengah Pertama, Sekolah Menengah Atas dan Sekolah Menengah Kejuruan terhadap profesionalisme guru dalam menerapkan media teknologi untuk meningkatkan kualitas pembelajaran. Dari kajiannya, dia menyimpulkan bahwa "52,75\% guru Sekolah Dasar, Sekolah Menengah Pertama, Sekolah Menengah Atas dan Sekolah Menengah Kejuruan menyatakan jarang menggunakan laptop", dalam melaksanakan proses pembelajaran di sekolah. 
Dari ulasan kajian sebelumnya di atas dapat diketahui bahwa kajian terhadap pelaksanaan pembelajaran di SMA wilayah pesisir kepulauan Buton belum dilakukan oleh para ahli lain. Oleh karena itu, kajian ini diharapkan dapat memberikan sumbangan bagi pemerintah dan akademisi dalam memahami pelaksanaan pembelajaran pada masa pandemic Covid-19 di wilayah pesisir kepulauan Buton sehingga hasil kajian ini nantinya diharapkan dapat menjadi acuan bagi pengambilan kebijakan oleh pemerintah, dan menjadi acuan bagi ahli lainnya dalam pengembangan strategi pembelajaran berbasis bencana.

Berdasarkan uraian di atas adalah penting untuk ditekankan bahwa kajian ini bertujuan untuk menjelaskan dan memahami pelaksanaan pembelajaran Sekolah Menengah Atas (SMA) pada masa pandemic Covid-19 di wilayah pesisir kepulauan Buton. Untuk menjelaskan dan memahami persoalan tersebut, maka tulisan ini akan menguraikan dua hal berikut ini. Pertama, tulisan ini menjelaskan bagaimana problematika pelaksanaan pembelajaran yang dihadapi oleh guru dan sekolah SMA di wilayah pesisir kepulauan Buton selama Pandemi Covid-19. Kedua, tulisan ini menjelaskan bagaimana strategi yang dilakukan oleh guru dan sekolah untuk mengatasi persoalan yang dihadapi selama pelaksanaan pembelajaran pada masa Pandemi Covid-19

\section{Metode Penelitian}

Penelitian ini merupakan jenis penelitian kualitatif deskriptif (Sugiyono, 2015) karena data yang digunakan bersifat kualitatif (F. A. Mansyur et al., 2021; F.A Mansyur, 2018; Firman Alamsyah Mansyur \& Suherman, 2020). Penelitian ini dilaksanakan mulai Bulan Oktober sampai dengan Desember 2020. Informan ditentukan melalui teknik cluster random sampling dari beberapa SMA. Responden tersebut berasal dari perwakilan unsur guru, kepala sekolah, peserta didik dan orang tua peserta didik pada jenjang Sekolah Menengah Atas (SMA) Negeri di Kepulauan Buton yang tersebar di Kota Baubau, Kabupaten Buton, Kabupaten Buton Selatan, Buton Tengah, dan Wakatobi. Penelitian ini menggunakan data primer yang diperoleh melalui pemberian angket secara online dengan bantuan google formulir, wawancara dan observasi. Data sekunder yang diperoleh melalui kajian literature. Validitas angket penelitian ini yaitu validitas isi dan konstruk yang ditempuh melalui penilaian oleh dua orang ahli. Berdasarkan validasi ahli maka angket yang digunakan dinyatakan valid. Analisis data dilakukan melalui beberapa tahapan berikut ini, yaitu: reduksi data, penyajian data, dan penarikan kesimpulan (Miles et al., 2014) Model Penelitian Analisis Pembelajaran ini mengikuti skema pada gambar 1 berikut. 


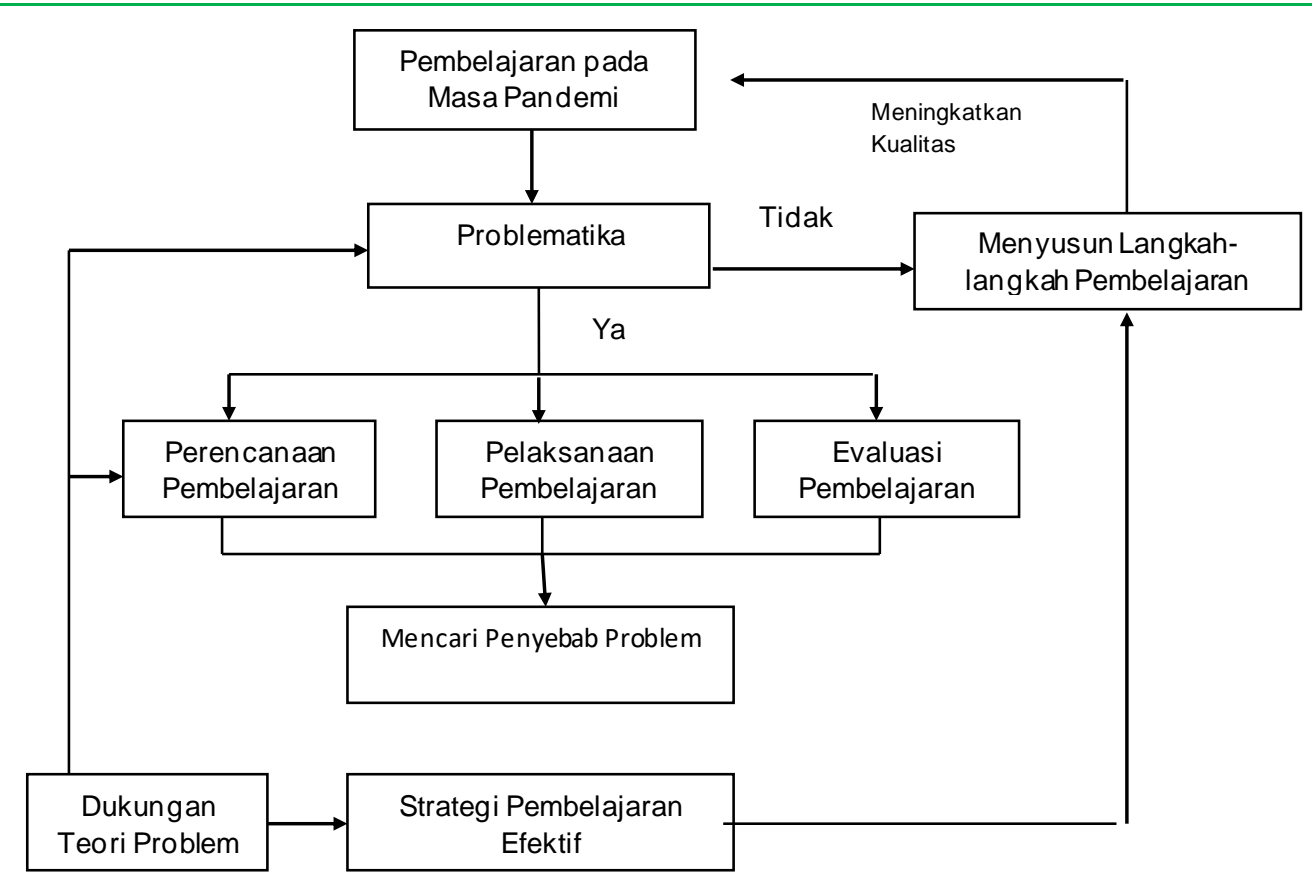

Gambar 1. Model Penelitian

\section{Hasil dan Pembahasan}

\subsection{Problematika Pembelajaran pada Masa Pandemi Covid-19 di Wilayah Pesisir Kepulauan Buton}

Pandemi Covid-19 membawa perubahan besar bagi penyelenggaraan pembelajaran di kepulauan Buton. Perubahan tersebut menuntut penyelenggara pendidikan di satuan pendidikan termasuk guru untuk melakukan adaptasi. Adaptasi pembelajaran yang memunculkan berbagai problematika dalam pelaksanaannya. Hasil penelitian menunjukkan bahwa problematika pembelajaran di Kepulauan Buton pada masa pandemi dikategorikan menjadi problematika yang dialami oleh kepala sekolah, guru, peserta didik, dan orang tua peserta didik.

Problematika yang dihadapi oleh informan berbeda-beda pada masa pandemi di wilayah pesisir Kepulauan Buton, hal tersebut disebabkan oleh kon disi sarana dan prasarana yang menunjang, kemampuan guru dalam mengelola pembelajaran, kesiapan peserta didik dalam belajar serta dukungan yang diberikan oleh orang tua kepada peserta didik ketika belajar. Problematika pembelajaran yang dihadapi di kepulauan Buton selama masa Pandemi Covid-19 dikelompokkan berdasarkan strategi yang dilakukan oleh sekolah dalam penyelenggaraan pembelajaran. Berdasarkan strategi tersebut, sekolah menyelenggarakan tiga kategori yakni pembelajaran online, pembelajaran kunjungan rumah dan pembelajaran tatap muka. Problematika yang dihadapi pada pembelajaran online tertera pada Tabel 1, 2, dan 3.

Bahasoan dkk. (2020) menjelaskan bahwa pada dasarnya system pembelajaran daring dalam masa Pandemi Covid-19 sangat efektif tetapi tidak efisien. Model pembelajaran daring sangat efektif karena sesuai kebutuhan pada masa Pandemi yang melarang terjadinya pembelajaran secara tatap muka, namun 
demikian pembelajaran daring tidak efisien Karena biaya yang dibutuhkan sangat mahal jika dibandingkan pembelajaran offline. Anugrahana (2020) dalam kajiannya terhadap pembelajaran di Yogyakarta menjelaskan bahwa hambatan dalam pembelajaran daring adalah sebagai berikut: (a) kemampuan guru yang rendah dalam penggunaan media pembelajaran berbasis daring sehingga hanya menggunakan WhatsApps (WA), padahal media ini sangat memiliki keterbatasan, (b) masih ada siswa yang tidak memiliki media Teknologi untuk digunakan dalam pembelajaran daring, misalnya HP atau Laptop, dll. (c) jaringan internet yang tidak stabil, (d) kemampuan orang tua/siswa untuk memenuhi kebutuhan ku ota internet.

Gunawan dkk. (2020) dalam kajiannya terhadap pelaksanaan pembelajaran di Perguruan Tinggi pada masa Pandemi menjelaskan bahwa semua dosen di Mataram sudah melaksanakan pembelajaran secara daring. Namun demikian, sebagian besar masih menggunakan Aplikasi WhatsApps. Padahal aplikasi ini sangat memiliki keterbatasan dalam pembelajaran. Beberapa dosen sudah menggunakan LMS Moodle daring, dan Google Classroom. Problematika yang dihadapi dalam pelaksanaan pembelajaran daring adalah terkait keterbatasan akses internet oleh mahasiswa dan dosen, dan kemampuan mahasiswa untuk membeli kuota internet yang rendah.

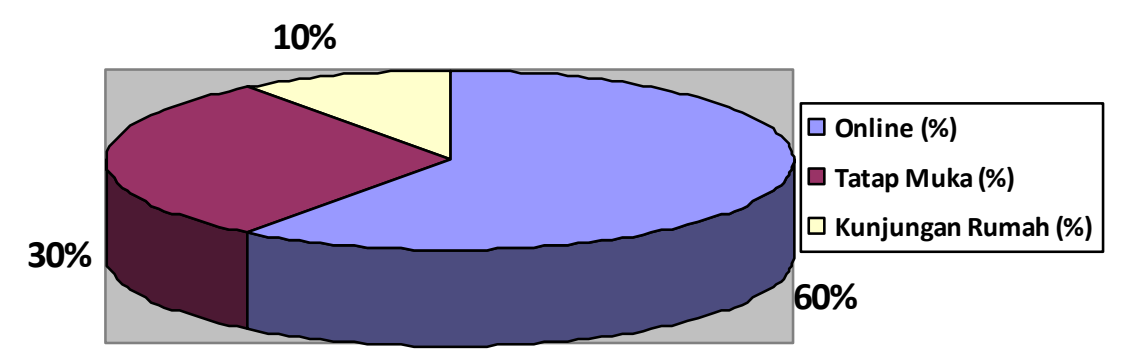

Gambar 2. Persentase Sekolah yang menyelenggarakan Pembelajaran online, tatap muka, dan kunjungan rumah

Tabel 1. Problematika yang Dihadapi pada Pembelajaran Online

\begin{tabular}{lll}
\hline No. & Responden & Problematika yang dihadapi \\
\hline 1. & Kepala Sekolah & a.
\end{tabular}




\begin{tabular}{|c|c|c|c|}
\hline & & $\begin{array}{l}\text { g. } \\
\text { h. } \\
\text { i. }\end{array}$ & $\begin{array}{l}\text { online } \\
\text { Penguasaan IT untuk pembelajaran online } \\
\text { Kesulitan menyelenggarakan praktikum } \\
\text { Belum adanya contoh best practice maupun pelatihan } \\
\text { belajar online yang diberikan kepada guru. }\end{array}$ \\
\hline 3. & Peserta didik & $\begin{array}{l}\text { a. } \\
\text { b. } \\
\text { c. }\end{array}$ & $\begin{array}{l}\text { Kurangnya pendampingan belajar dari guru } \\
\text { Tugas belajar yang meningkat dari biasanya } \\
\text { Motivasi yang rendah }\end{array}$ \\
\hline 4. & $\begin{array}{lll}\text { Orang } & \text { Tua } & \text { Peserta } \\
\text { didik } & & \end{array}$ & $\begin{array}{l}\text { a. } \\
\text { b. } \\
\text { c. }\end{array}$ & $\begin{array}{l}\text { Penyediaan gawai bagi peserta didik } \\
\text { Penyediaan pulsa internet untuk peserta didik } \\
\text { Sulit member pendampingan untuk semua mata } \\
\text { pelaiaran peserta didik. }\end{array}$ \\
\hline
\end{tabular}

Sumber: diolah dari hasil penelitian (2020)

Tabel 2. Problematika yang Dihadapi pada Pembelajaran Tatap Muka

\begin{tabular}{llll}
\hline No. & Responden & Problematika yang dihadapi \\
\hline 1. & Kepala Sekolah & a. & $\begin{array}{l}\text { Kesulitan dalam menerapkan pembelajaran yang } \\
\text { menerapkan protokol kesehatan yang ketat bagi } \\
\text { pembelajaran tatap muka }\end{array}$
\end{tabular}

\begin{tabular}{|c|c|c|}
\hline & Guru & $\begin{array}{l}\text { a. Penyesuaian perangkat pembelajaran dengan situasi } \\
\text { pandemi Covid-19 } \\
\text { b. Kesulitan dalam menyelenggarakan pembelajaran } \\
\text { dengan jam pelajaran yang berkurang } \\
\text { c. Pemilihan metode pembelajaran yang tepat dalam } \\
\text { d. Pembelajaran } \\
\text { e. Pemyesuaian desain tugas bagi peserta didik } \\
\text { e. Pemilihan asesmen yang tepat bagi pembelajaran }\end{array}$ \\
\hline 3. & Peserta Didik & $\begin{array}{l}\text { a. Berkurangnya jam pembelajaran menjadikan peserta } \\
\text { didik harus meningkatkan kemandirian belajarnya. } \\
\text { b. Beban tugas yang meningkat } \\
\text { c. Rendahnya motivasi belajar peserta didik }\end{array}$ \\
\hline 4. & $\begin{array}{lll}\begin{array}{l}\text { Orang } \\
\text { didik }\end{array} & \text { Tua } & \text { Peserta } \\
\end{array}$ & $\begin{array}{l}\text { a. Kesulitan dalam mendesain pembelajaran untuk jam } \\
\text { belajar yang berkurang } \\
\text { b. Kesulitan untuk menerapkan penilaian pembelajaran } \\
\text { yang tepat }\end{array}$ \\
\hline
\end{tabular}

Sumber: diolah dari hasil penelitian (2020)

Tabel 3. Problematika yang Dihadapi pada Pembelajaran Kunjungan Rumah

\begin{tabular}{|c|c|c|}
\hline No. & Responden & Problematika yang dihadapi \\
\hline & Kepala Sekolah & $\begin{array}{l}\text { a. Kesulitan mengontrol pembelajaran } \\
\text { b. Kesulitan dalam menyediakan perlengkapan yang } \\
\text { menunjang pembelajaran kunjungan rumah } \\
\text { c. Kesulitan dalam memberikan dukungan terhadap } \\
\text { operasional guru dalam pembelajaran kunjungan rumah }\end{array}$ \\
\hline & Guru & $\begin{array}{l}\text { a. Beban mengajar yang meningkat karena kelas normal } \\
\text { menjadi terbagi pada pembelajaran kunjungan rumah } \\
\text { b. Tenaga yang dibutuhkan menjadi meningkat } \\
\text { c. Sulitnya mengkoordinir peserta didik saat pembelajaran } \\
\text { kunjungan rumah } \\
\text { d. Penyesuaian desain pembelajaran dan penilaian pada } \\
\text { pembeljaaran kunjungan rumah } \\
\text { e. Kesulitan menyelenggarakan praktikum }\end{array}$ \\
\hline
\end{tabular}




\begin{tabular}{|c|c|c|c|}
\hline & & & f. Kesulitan apabila rumah peserta didik saling berjauhan \\
\hline 3. & Peserta Didik & & a. Ketersediaan buku paket yang kurang di rumah \\
\hline 4. & $\begin{array}{ll}\text { Orang } & \text { Tua } \\
\text { didik }\end{array}$ & Peserta & a. Penyediaan perlengkapan belajar di rumah \\
\hline
\end{tabular}

Sumber: diolah dari hasil penelitian (2020)

\subsection{Strategi Pembelajaran pada Masa Pandemi Covid-19 di Wilayah Pesisir Kepulauan Buton}

Dari hasil analisis data ditemukan bahwa terdapat berbagai strategi yang telah dilakukan oleh sekolah dan guru untuk menciptakan pembelajaran efektif pada masa Pandemi-Covid-19. Strategi pembelajaran tersebut secara umum dapat dibagi dua, yaitu: strategi pembelajaran efektif bagi sekolah yang tetap melaksanakan pembelajaran tatap muka atau luring karena tidak memiliki jaringan internet yang stabil dan perangkat pembelajaran yang memadai, dan strategi pembelajaran efektif bagi sekolah yang dapat menerapkan pembelajaran daring.

\section{a. Strategi pembelajaran dengan model belajar luring.}

Data lapangan menunjukkan bahwa dari 10 SMA di wilayah pesisir kepulauan Buton, khususnya wilayah Kabupaten Buton, Buton Tengah, Buton Selatan dan Wakatobi, sebagian besar melakukan pembelajaran secara tatap muka atau lu ring di kelas. Beberapa guru SMA di Kabupaten Buton melakukan pembelajaran melalui kunjungan rumah siswa karena adanya larangan melakukan pembelajaran di sekolah. Oleh karena itu, sekolah SMA di wilayah pesisir kepulauan Buton umumnya menerapkan strategi pembelajaran luring sebagai berikut ini.

a. Pengelolaan pelaksanaan pembelajaran efektif di dalam kelas atau kunjungan rumah siswa harus tetap dijalankan namun dengan waktu yang terbatas.

b. Guru tetap berupaya membangun proses komunikatif yang baik dengan siswa agar dapat memahami pelajaran, dan menciptakan kemandirian belajar siswa.

c. Guru tetap berupaya memberikan kesempatan bagi peserta didik untuk memberikan respon terhadap materi pelajaran yang diberikan dengan memaksimalkan media pembelajaran yang bisa digunakan, dan memperhatikan waktu tatap muka yang diberikan.

d. Guru berupaya menciptakan aktivitas belajar siswa yang aktif, kreatif, dan mandiri melalui tugas-tugas yang diberikan secara terstruktur, mudah dipahami, dan dapat dikerjakan oleh siswa.

e. Guru tetap melakukan evaluasi terhadap hasil belajar siswa sesuai dengan tugas-tugas yang diberikan.

f. Guru berupaya membangun komunikasi dengan orang tua siswa dan membangun komunitas belajar di luar sekolah.

Pembelajaran luring merupakan model yang harus tetap digunakan bagi sebagian besar sekolah yang daerahnya kesulitan mengakses jaringan internet. Sekolah dan guru SMA di Kabupaten Buton, Buton Selatan, Buton Tengah dan Wakatobi, tetap berupaya melakukan pembelajaran efektif melalui tatap muka atau 
luring pada situasi pandemi. Pelaksanaan pembelajaran secara luring di tengah pandemic Covid-19 tentunya sangat beresiko karena dapat menyebarkan virus Covid-19. Namun demikian, model pembelajaran ini tetap digunakan dengan memperhatikan protokol kesehatan dan data penyebaran Covid-19 di daerah tersebut yang pada saat itu dianggap masih aman untuk melaksanakan pembelajaran secara luring.

Hasil temuan ini menunjukkan bahwa dalam pembelajaran luring, guru sekolah SMA di wilayah pesisir kepulauan Buton tetap berupaya melaksanakan pembelajaran efektif walaupun tidak optimal. Bistari (2017) menekankan adanya lima indikator pembelajaran efektif yang harus dipenuhi oleh sekolah dan guru, yaitu: 1) pengelolaan pelaksanaan pembelajaran, 2) proses komunikatif, 3) respon peserta didik, 4) aktivitas belajar, 5) hasil belajar. Lima indicator ini tetap menjadi acuan bagi guru-guru SMA di wilayah pesisir kepulauan Buton dalam melaksanakan pembelajaran efektif namun pelaksanannya tidaklah optimal karena penggunaan waktu yang sangat terbatas.

Guru-guru SMA sudah berupaya membangun strategi belajar yang berfokus pada siswa agar menciptakan keaktifan dan kemandirian siswa dalam belajar. Utami (2009) menjelaskan bahwa untuk mewujudkan pembelajaran efektif maka guru seharusnya menerapkan strategi belajar aktif. Strategi ini memberikan kesempatan bagi peserta didik agar dapat melaksanakan aktivitas belajar dengan baik dan menjadikan pembelajaran lebih bermakna. Guru hanya menjadi fasilitator dalam pembelajaran. Bidabadi et al. (2016) menyatakan bahwa metode campuran antara student-centered dan teacher centered dipadu dengan perencanaan pembelajaran yang baik serta kesiapan siswa dalam mengikuti pembelajaran menjadi faktor yang mendukung pembelajaran berjalan secara efektif. Karenanya, kedua strategi tersebut dapat digunakan pada saat pandemic Covid-19 yang membatasi ruang gerak manusia untuk berjumpa.

Hasil analisis data juga menunjukkan adanya upaya guru SMA untuk mengelola kelas dengan baik walaupun waktu mengajar mereka sangat singkat. Arfani dan Sugiyono (2014) menyatakan bahwa untuk menciptakan manajemen kelas yang efektif dicapai apabila tiga unsur substantif yaitu pengelolaan perilaku, pengelolaan lingkungan dan pengelolaan kurikulum dan instruksional dijalankan dengan baik.

\section{b. Strategi pembelajaran dengan model belajar Daring}

Pelaksanaan pembelajaran daring di Sekolah Menengah Atas (SMA) di wilayah pesisir Kepulauan Buton pada dasarnya hanya dilakukan di beberapa sekolah karena ketersedian jaringan internet yang stabil. Karenanya, dari pengumpulan data di beberapa SMA ditemukan beberapa strategi yang digunakan oleh guru untuk tetap membangun pembelajaran efektif, yaitu sebagai berikut ini.

a. Sebagian besar sekolah dan guru menggunakan beberapa platform pembelajaran yang dapat diakses oleh siswa, misalnya WhatsApps, email, ruang belajar guru, youtube, Video Pembelajaran.

b. Guru tetap berupaya melakukan Pengelolaan pelaksanaan pembelajaran efektif berbasis pembelajaran daring. 
c. Guru berupaya memperhatikan penggunaan waktu pembelajaran agar siswa tidak jenuh dan paket internet siswa tidak cepat habis agar dapat mengikuti pelajaran secara berkelanjutan.

d. Guru berupaya membangun proses komunikatif yang baik dengan siswa agar dapat memahami pelajaran, dan menciptakan kemandirian belajar siswa melalui platform pembelajaran WhatsApps, email, ruang belajar guru, youtube, Video Pembelajaran.

e. Guru harus berupaya memberikan kesempatan kepada peserta didik untuk memberikan respon terhadap materi pelajaran yang diberikan dengan memaksimalkan media pembelajaran yang bisa digunakan.

f. Guru berupaya menciptakan aktivitas belajar siswa yang aktif, kreatif, dan mandiri melalui tugas-tugas yang diberikan secara terstruktur, mudah dipahami, dan dapat dikerjakan oleh siswa di rumah.

g. Guru sudah berupaya tetap melakukan evaluasi terhadap hasil belajar siswa sesuai dengan tugas-tugas yang diberikan melalui media pembelajaran daring.

h. Guru berupaya membangun komunikasi dengan orang tua siswa agar dapat mendampingi siswa belajar aktif di rumah secara mandiri

Dari gambaran data di atas dapat diketahui adanya upaya yang dilakukan sebagian besar guru-guru SMA di wilayah pesisir kepulauan Buton untuk melakukan pembelajaran daring namun belum optimal. Dalam pembelajaran daring, guru SMA kebanyakan masih menggunakan whatsApps, belum banyak yang mengoptimalkan penggunaan Googleclassroom, video, yutobe, atau lain nya. Padahal, keberhasilan pembelajaran daring di Indonesia pada masa Covid-19 sangat ditentukan oleh kesiapan teknologi yang selaras dengan kurikulum nasional, dukungan dan kolaborasi para stakeholder, pemerintah, sekolah, guru, orang tua, dan komunitas (Rasmitadila et al., 2020). Penggunaan media daring oleh guru SMA yang daerah memiliki jaringan internet yang baik pada dasarnya sudah tepat sesuai situasi pandemic. Media pembelajaran daring merupakan solusi bagi pembelajaran di masa pandemic karena memiliki beberapa kelebihan berikut ini: a) pembelajaran daring sangat praktis dan santai, b) pembelajaran daring sangat fleksibel karena bisa dilakukan kapanpun dan dimanapun, c) pembelajaran daring sangat menghemat waktu, d) dapat memberikan kemudahan bagi guru dalam penilaian Anugrahana (2020). Namun menurutnya, keterlibatan siswa sangat kurang maksimal dalam pembelajaran daring.

Jika kita mengacu pada strategi pembelajaran efektif yang dilakukan oleh guru SMA, maka pada dasarnya pandangan Anugrahana terkait kelemahan pembelajaran daring tidak sepenuhnya benar. Untuk membangun keaktifan dan kemandirin belajar siswa, guru dapat memberikan tugas secara terstruktur untuk dikerjakan oleh siswa di rumah dengan pendampingan orang tua. Sebagai fasilitator dan penyelenggara kegiatan pembelajaran, guru perlu memanfaatkan segala sumber daya yang ada dan mengelola setiap komponen yang terlibat dalam kegiatan pembelajaran dalam rangka mendorong pembelajaran yang efektif dan pencapaian tujuan pembelajaran secara optimal (Astuti, 2019). Selain itu, untuk menyelenggarakan pembelajaran yang optimal, guru perlu mengidentifikasi dan melaksanakan pembimbingan kepada siswa sesuai dengan karakteristik siswa 
tersebut dalam proses pembelajaran karena ada pengaruh yang positif antara bimbingan guru dan motivasi belajar terhadap prestasi belajar siswa (Sukirman, 2011).

Pemanfaatan media pembelajaran daring oleh beberapa guru SMA di wilayah pesisir kepulauan Buton pada dasarn ya belum optimal karena masih banyak hal atau fitur media pembelajaran daring yang belum digunakan. Miftah (2013) menjelaskan bahwa media pembelajaran dapat membantu siswa dalam memahami materi pembelajaran. Oleh karena itu, penting bagi guru untuk memiliki keterampilan dalam memilih dan mengembangkan media pembelajaran yang tepat bagi setiap tujuan belajar yang hendak dicapai oleh siswa. Susilawati (2020) menganjurkan rumah belajar sebagai solusi pelaksanaan pembelajaran pada sekolah berdampak bencana. Model bentuk pemanfaatan rumah belajar melalui rumah belajar secara daring, sumber belajar: video, dan bahan belajar interaktif tersebut pada dasarnya dapat diadaptasikan dalam proses pembelajaran pada masa Covid-19 ini.

Temuan Susilawati tersebut dapat dijadikan acuan dalam pengembangan strategi pembelajaran berbasis daring bagi sekolah SMA di wilayah pesisir kepulauan Buton, khususnya Sekolah SMA Muhammadiyah di Kota Baubau. Media pembelajaran daring jika digunakan secara optimal dapat membantu mengatasi persoalan pelaksanaan pembelajaran pada masa pandemic Covid-19. Sayangnya, penggunaan media pembelajaran daring dalam pembelajaran membutuhkan kesiapan banyak hal, baik itu jaringan, kepemilikan perangkat pembelajaran daringnya, penguasaan teknonologi pembelajaran berbasis digital, dan kesiapan orang tua, dan siswa untuk melaksanakan dan mengikuti pembelajaran daring secara sistematis.

Untuk menghindari kebosanan siswa dalam pembelajaran daring, guru SMA juga perlu menggunakan game multimedia sebagai intrumen pembelajaran. Sangsawang (2020) mengemukakan bahwa game multimedia dapat digunakan sebagai instrumen untuk kegiatan berpikir kritis berdasarkan keran gka kerja SelfRegulated Learning (SRL) untuk krisis Covid-19, didukung untuk meningkatkan kemampuan siswa. Uraian di atas menunjukkan pada kita bahwa pada dasarnya strategi pembelajan efektif tidaklah bersifat kaku namun adaptif dan fleksibel terhadap situasi dan kondisi yang dihadapi oleh guru sekolah. Oleh karena itu, para guru hendaknya mampu menguasai pelbagai strategi pembelajaran dan kemampuan menggunakan teknologi.

Manthalkar dkk (2020) menjelaskan bahwa restrukturisasi pendidikan setelah Covid-19 membutuhkan empat pilar berikut ini, yaitu: (a) fleksibilitas, (b) kecerdasan kognitif, sosial dan spiritual, (c) ketahanan (bangkit kembali meskipun gagal), dan (d) pemikiran kreatif \& pemikiran desain. Pengikatnya adalah pembelajaran seumur hidup. Manusia hendaknya senantiasa belajar sejak sejak lahir sampai mati. Pandemi Covid-19 adalah tantangan bagi manusia agar dapat menggunakan dan mengembangkan kemampuan kreatifnya untuk bertahan hidup, dan saling membantu satu sama lain dalam mengisi peradaban di muka bumi ini.

\section{Kesimpulan}

Dari uraian di atas dapat disimpulkan dua hal mendasar terkait problematika dan strategi pembelajaran efektif pada masa pandemic Covid-19. Pertama, problematika yang dihadapi dapat dibagi atas problematika yang dihadapi pada 
pembelajaran luring, baik itu di sekolah maupun, kunjungan rumah, dan problematika pada saat pembelajaran daring. Hasil kajian ini menunjukkan bahwa situasi pandemic mengharuskan semua orang saling menjaga jarak dan memakai masker sangat menyulitkan pelaksanaan pembelajaran di sekolah atau kunjungan rumah yang cenderung dipaksakan karena ketidaksiapan atau ketidakmampuan sekolah menyiapkan pembelajaran pada masa krisis berbasis pembelajaran daring. Kepala sekola, guru, para orang tua, dan peserta didik berupaya tetap melaksanakan pembelajaran dengan jumlah waktu mengajar yang singkat. Beberapa sekolah SMA di wilayah pesisir kepulauan Buton ada yang sudah menggunakan pembelajaran daring namun tetap belum optimal akibat penguasa $\mathrm{n}$ media pembelajaran daring yang masih kurang dari para guru sehingga cenderung menggunakan platform WhatsApps yang kurang interaktif dan kurang menarik. Guru juga kesulitan mengontrol keaktifan siswanya dengan perangkat pembelajaran tersebut. Kedua, guru pada dasarnya tetap berupaya melaksanakan strategi pembelajaran efektif di mana semua unsur-unsur penting dalam pembelajaran efektif tetap dilakukan dalam pembelajaran namun belumlah optimal. Hal ini terjadi karena situasi Covid yang membatasi jarak, memakai masker, penggunaan waktu yang lebih singkat, menjadikan guru memiliki keterbatasan dalam menjelaskan dan berdiskusi dengan siswa. Dalam pembelajaran daring, strategi beberapa guru SMA di wilayah pesisir Kepulauan Buton sebagian besar hanya mengandalkan perangkat WhatsApps.

Hasil kajian ini secara keseluruhan menekankan bahwa pelaksanaan pembelajaran SMA di wilayah pesisir Kepulauan Buton tidak berjalan efektif karena ketidaksiapan menyikapi Pandemi Covid-19. Ketidaksiapan ini merupakan persoalan yang kompleks karena terkait dengan banyak hal, yaitu: minimnya sarana dan prasarana penunjang pembelajaran berbasis daring, jaringan internet yang tidak stabil, ketidaksiapan guru menggunakan teknologi pembelajaran berbasis daring, siswa tidak memiliki smartphone atau perangkat pembelajaran daring, dan kemandirian belajar siswa yang rendah, serta peranan orang tua dalam pendampingan siswa yang masih rendah..

\section{Ucapan Terima Kasih}

Penelitian ini merupakan penelitian yang dibiayai oleh program Hibah RisetMu Batch 4 Majelis Diktilitbang PP Muhammadiyah. Oleh karena itu, peneliti mengucapkan terima kasih banyak kepada Majelis Diktilitbang PP Muhammadiyah. Selain itu, peneliti juga mengucapkan terima kasih kepada LPPM UM Buton yang telah menfasilitasi peneliti mendapatkan hibah penelitian tersebut.

\section{Daftar Pustaka}

Abidin, Z., Rumansyah, \& Arizona, K. (2020). Pembelajaran Online Berbasis Proyek Salah Satu Solusi Kegiatan Belajar Mengajar di Tengah Pandemi COVID-19. Jurnal IImiah Profesi Pendidikan, 5(1).

Anugrahana, A. (2020). Hambatan, Solusi dan Harapan: Pembelajaran Daring Selama Masa Pandemi Covid-19 Oleh Guru Sekolah Dasar. Scholaria Jurnal Pendidikan Dan Kebudayaan, 10(3). https://doi.org/https://doi.org/10.24246/j.js.2020.v10.i3.p282-289

Arfani, J. W., \& Sugiyono. (2014). Manajemen Kelas yang Efektif:Penelitian di 
Tiga Sekolah Menengah Atas. Akuntabilitas Manajemen Pendidikan, 2(1), 4457. https://doi.org/https://doi.org/10.21831/amp.v2i1.2408

Astini, N. K. S. (2020). Tantangan Dan Peluang Pemanfaatan Teknologi Informasi Dalam Pembelajaran Online Masa Covid-19. Cetta Jurnal IImu Pendidikan, 3(2). https://doi.org/https://doi.org/10.37329/cetta.v3i2.452

Astuti. (2019). Manajemen Kelas yang Efektif. Adaara: Jurnal Manajemen Pendidikan Islam, 9(2), 892-907.

Bahasoan, A. N., Ayuandiani, W., Mukhram, M., \& Rahmat, A. (2020).

Effectiveness of Online Learning In Pandemic Covid-19. International Journal of Science, Technology and Management, 1(2).

https://doi.org/https://doi.org/10.46729/ijstm.v1i2.30

Bidabadi, N. S., Isfahani, A. N., Rouhollah, A., \& Khalili, R. (2016). Effective teaching methods in higher education: Requirements and barriers. Journal of Advances in Medical Education \& Professionalism, 4(4), 170-178.

Bistari. (2017). Konsep Dan Indikator Pembelajaran Efektif. Jurnal Kajian Pembelajaran Dan Keilmuan, 1(2).

Gunawan, Suranti, N. M. Y., \& Fathoroni. (2020). Variations of Models and Learning Platforms for Prospective Teachers During the COVID-19 Pandemic Period. Indonesian Journal of Teacher Education, 1(2).

Harahap, A. C. P., Harahap, D. P., \& Harahap, S. . (2020). Analisis Tingkat Stres Akademik Pada Mahasiswa Selama Pembelajaran Jarak Jauh Dimasa Covid19. Biblio Couns Jurnal Kajian Konseling Dan Pendidikan, 3(1). https://doi.org/http://dx.doi.org/10.30596\%2Fbibliocouns.v3i1.4804

Hartomo, G. (2020, April). 433 Desa Belum Teraliri Listrik, Jokowi: Identifikasi! Okezone.

Hutami, M. S., \& Nugraheni, A. S. (2020). Metode Pembelajaran Melalui Whatsapp Group Sebagai Antisipasi Penyebaran Covid-19 pada AUD di TK ABA Kleco Kotagede. Paudia Jurnal Penelitian Dalam Bidang Pendidikan Anak Usia Dini, $9(1)$.

Jamal, S. (2020). Analisis Kesiapan Pembelajaran E-LEARNING Saat Pandemi COVID-19 DI SMK Negeri 1 Tambelangan. Jurnal NalarPendidikan, 8(1). https://doi.org/https://doi.org/10.26858/jnp.v8i1.13561

Mansyur, A. R. (2020). Dampak COVID-19 Terhadap Dinamika Pembelajaran Di Indonesia. Eljour Education and Learning Journal, 1(2). https://doi.org/http://dx.doi.org/10.33096/eljour.v1i2.55

Mansyur, F. A., Nuryadin, C., \& Muchtar, M., Sahril, S., Amayliya, W. O. A. (2021). Character Education Values in Indonesian Proverbs. ELS Journal on Interdisciplinary Studies in Humanities, 4(3), 346-354. https://doi.org/10.34050/elsjish.v4i3.18017.

Mansyur, F.A. (2018). Onina Manga Mancuana Mangenge: Ungkapan Tradisional Orang Wolio, Doctoral Dissertaiton. Universitas Gajah Mada. Retrieved from: http://digilib.fib.ugm.ac.id/digital/filter/960

Mansyur, Firman Alamsyah, \& Suherman, L. A. (2020). The Function of Proverbs 
as Educational Media: Anthropological Linguistics on Wolio Proverbs. ELS Journal on Interdisciplinary Studies in Humanities, 3(2), 271-286. https://doi.org/10.34050/els-jish.v3i2.10505

Manthalkar, R., Gajre, S., \& Joshi, Y. (2020). Education after covid-19 disruption. Easychair Preprint, 3431.

Miftah, M. (2013). Fungsi dan Peran Media Pembelajaran sebagai Upaya Peningkatan Kemampuan Belajar Siswa. Kwangsan Jurnal Teknologi Pendidikan, 1(2), 95-105.

https://doi.org/https://doi.org/10.31800/jtp.kw.v1n2.p95--105

Miles, M. B., Huberman, A., \& Saldaña, J. (2014). Qualitative data analysis: A methods Sourcebook (3rd Edition). In SAGE Publications, Inc. https://doi.org/10.1177/239700221402800402

Mulyaningsih, I. E. (2014). pengaruh interaksi sosial keluarga, motivasi belajar, dan kemandirian belajar terhadap prestasi belajar. Jurnal Pendidikan Dan Kebudayaan, 20(4). https://doi.org/https://doi.org/10.24832/jpnk.v20i4.156

Novita, M. (2017). Sarana dan prasarana yang baik menjadi ujung tombak keberhasilan lembaga pendidikan islam. Jurnal Pendidikan Dan Sosial Keagamaan, 4(2).

Nurhayati, E. (2020). Meningkatkan keaktifan siswa dalam pembelajaran daring melalui media game edukasi quiziz ada masa pencegahan penyebaran covid19. Jurnal Paedagogy Jurnal Penelitian Dan Pengembangan Pendidikan, 7(3). https://doi.org/https://doi.org/10.33394/jp.v7i3.2645

Oktawirawan, D. H. (2020). Faktor Pemicu Kecemasan Siswa dalam Melakukan Pembelajaran Daring di Masa Pandemi Covid-19. Jurnal IImiah Universitas Batanghari Jambi, 20(2). https://doi.org/http://dx.doi.org/10.33087/jiubj.v20i2.932

Pertiwi, R. E., \& Syakarofath, N. (2020). Family Strength Model dalam Upaya Meningkatkan Ketangguhan Keluarga di Situasi Kritis. ALTRUIS: Journal of Community Services, 1(20). https://doi.org/https://doi.org/10.22219/altruis.v1i2.12283

Purwanto, A., Pramono, R., Asbari, M., Hyun, C. C., Wijayanti, L. M., Putri, R. S., \& Santoso, P. B. (2020). Studi Eksploratif Dampak Pandemi COVID-19 Terhadap Proses Pembelajaran Online di Sekolah Dasar. EduPsyCouns: Journal of Education, Psychology and Counseling, 2(1), 1-12.

Rasmitadila, R., Aliyyah, R. R., Rachmadtullah, A., Samsudin, A., Syaodih, E., Nurtanto, M., \& Tambunan, A. R. S. (2020). The Perceptions of Primary School Teachers of Online Learning during the COVID-19 Pandemic Period: A Case Study in Indonesia. Journal of Ethnic and Cultural Studies, 7(2). https://doi.org/http://dx.doi.org/10.29333/ejecs/38

Sangsawang, T. (2020). An Instructional Design For Online Learning In Vocational Education According To A Self-Regulated Learning Framework For Problem Solving During The Covid-19 CRISIS. Indonesian Journal Of Science and Technology, 5(2). https://doi.org/https://doi.org/10.17509/ijost.v5i2.24702

Sari, L. (2020). Upaya Menaikkan Kualitas Pendidikan Dengan Pemanfaatan 
Youtube Sebagai Media Ajar Pada Masa Pandemi Covid-19. Jurnal Tawadhu, $4(1)$.

Sekretariat GTK. (2021). Kebijakan Kemendikbud di Masa Pandemi. Direktorat Jenderal Guru Dan Tenaga Kependidikan, Kementerian Pendidikan, Kebudayaan, Riset, Dan Teknologi, Republik Indonesia.

Sugiyono. (2015). Metode Penelitian Pendidikan: Penelitian Kuantitatif, Kualitatif, dan $R \& D$. Alfabeta.

Sukirman. (2011). Peranan Bimbingan Guru dan Motivasi Belajar dalam Rangka Meningkatkan Prestasi Belajar Peserta Didik SMA Negeri 1 Metro Tahun 2010. Guidena Jurnal IImu Pendidikan, Psikologi, Bimbingan Dan Konseling, 1(1), 23-35.

Sunhaji. (2014). Konsep Manajemen Kelas Dan Implikasinya Dalam Pembelajaran . Jurnal Kependidikan, 2(2). https://doi.org/https://doi.org/10.24090/jk.v9i1

Susilawati, E. (2020). Pemanfaatan Rumah Belajar Pada Sekolah Terdampak Bencana Gempa. Jurnal Pendidikan Dan Kebudayaan, 5(1). https://doi.org/https://doi.org/10.24832/jpnk.v5i1.1504

Syukur, I. A. (2014). Profesionalisme Guru dalam Mengimplementasikan Teknologi Informasi dan Komunikasi di Kabu paten Nganjuk. Jurnal Pendidikan Dan Kebudayaan, 20(2). https://doi.org/https://doi.org/10.24832/jpnk.v20i2.138

Utami, R. P. (2009). Active Learning untuk Mewujudkan Pembelajaran Efektif. AlBidayah, 1(3), 151-166.

Wang, Y., Peng, H., Huang, R., Hou, Y., \& Wang, J. (2008). Characteristics of distance learners: research on relationships of learning motivation, learning strategy, self-efficacy, attribution and learning results, Open Learning. The Journal of Open, Distance and E-Learning, 23(1), 17-28. https://doi.org/10.1080/02680510701815277

World Health Organization. (2021). Update on coronavirus disease in Indonesia. Coronavirus Disease (COVID-19). 